\title{
A Phylogenetic Analysis of the Genus Saccharomyces Based on 18S rRNA Gene Sequences: Description of Saccharomyces kunashirensis sp. nov. and Saccharomyces martiniae sp. nov. \\ STEPHEN A. JAMES, ${ }^{1}$ JUNPENG CAI,${ }^{2}$ IAN N. ROBERTS, ${ }^{1}$ AND MATTHEW D. COLLINS ${ }^{2 *}$ \\ National Collection of Yeast Cultures, Department of Genetics and Microbiology, Institute of Food Research, Norwich Laboratory, Norwich NR4 7UA, ${ }^{1}$ and Department of Microbiology, Institute of Food Research, Reading Laboratory, Reading RG6 $6 B Z,{ }^{2}$ United Kingdom
}

\begin{abstract}
A phylogenetic investigation of the ascomycetous yeast genus Saccharomyces was performed by using $18 \mathrm{~S}$ rRNA gene sequence analysis. Comparative sequence analysis showed that the genus is phylogenetically very heterogeneous. Saccharomyces species were found to be phylogenetically interdispersed with members of other ascomycetous genera (e.g., the genera Kluyveromyces, Torulaspora, and Zygosaccharomyces). The four species of the Saccharomyces sensu stricto complex (viz., Saccharomyces bayanus, Saccharomyces cerevisiae, Saccharomyces paradoxus, and Saccharomyces pastorianus) were found to be phylogenetically closely related to one another, displaying exceptionally high levels of sequence similarity $(\geq 99.9 \%)$. These four species formed a natural group that was quite separate from the other Saccharomyces and non-Saccharomyces species examined. Saccharomyces exiguus and its anamorph, Candida holmii, were found to be genealogically almost identical and, along with Saccharomyces barnettii, formed a stable group closely related to, but nevertheless distinct from, Kluyveromyces africanus, Kluyveromyces lodderae, Saccharomyces rosinii, Saccharomyces spencerorum, and Saccharomyces sp. strain CBS $7662^{\mathrm{T}}$ (T = type strain). Saccharomyces spencerorum and Kluyveromyces lodderae displayed a particularly close genealogical affinity with each other, as did Saccharomyces castellii and Saccharomyces dairensis. Similarly, Saccharomyces servazzii, Saccharomyces unisporus, and Saccharomyces sp. strain CBS 6904 were found to be genotypically highly related and to form a phylogenetically distinct lineage. The recently reinstated species Saccharomyces transvaalensis was found to form a distinct lineage and displayed no specific association with any other Saccharomyces or non-Saccharomyces species. Saccharomyces kluyveri formed a very loose association with a group which included Kluyveromyces thermotolerans, Kluyveromyces waltii, Zygosaccharomyces cidri, and Zygosaccharomyces fermentati. Saccharomyces sp. strain CBS $6334^{\mathrm{T}}$, on the other hand, displayed no specific association with any of the other Saccharomyces spp. studied, although a neighbor-joining analysis did reveal that this strain exhibited a loose phylogenetic affinity with Kluyveromyces polysporus and Kluyveromyces yarrowii. On the basis of the phylogenetic findings, two new Saccharomyces species, Saccharomyces kunashirensis (with type strain CBS 7662) and Saccharomyces martiniae (with type strain CBS 6334), are described.
\end{abstract}

The present system used to classify yeasts is based predominately on phenotypic characteristics and relies on metabolic features, such as fermentation reactions, and the morphology of the vegetative and (if present) sexual states of the yeasts. It is now recognized, however, that such characteristics may not always be sufficient for species delineation $(2,19)$, and interstrain variability in key fermentation test results often hampers good classification and therefore accurate identification. The genetic basis behind many of these characteristics is often either poorly understood or unknown, and there is a growing awareness that the present yeast taxonomy more often than not does not reflect evolutionary relationships between organisms (14). Knowledge of evolutionary relationships among bacteria has been revolutionized with the advent of small-subunit rRNA sequence analysis (30). This approach has started to gain ground in yeast systematics, and there have been a number of phylogenetic investigations in recent years $(4,5,9,11$, 13, 14). Nevertheless, rRNA sequence analysis of yeasts is still in its infancy, and far more systematic investigations will be required before a stable and robust yeast taxonomy based on phylogenetics is realized.

${ }^{*}$ Corresponding author. Mailing address: Department of Microbiology, Institute of Food Research, Reading Laboratory, Earley Gate Whiteknights Road, Reading, RG6 6BZ, United Kingdom. Phone: 44-1734-357226. Fax: 44-1734-267917. E-mail: David.Collins@BBSRC .AC.UK.
Over the years, the ascomycetous yeast genus Saccharomyces has undergone major alterations, which have closely parallelled changes which have taken place in yeast taxonomy in general (3). In particular, molecular genetic studies have started to have a major impact on the current taxonomy of the genus. To date, the most significant molecular taxonomic contributions to the genus Saccharomyces have come from nuclear DNA (nDNA)-nDNA hybridizations, which have brought about the reestablishment of several species names and have reduced other names to synonyms $(27,29)$, have resulted in descriptions of new species $(22,24)$, and have raised the likelihood of the existence of yet additional species (23). Although knowledge at the species level is undoubtedly much improved as a consequence of these studies, information about the phylogenetic coherence within the genus and about the evolutionary affinity of Saccharomyces species with members of other ascomycetous genera is currently very limited. Recent $18 \mathrm{~S}$ rRNA gene sequence analyses $(5,12)$ have revealed that $S a c$ charomyces cerevisiae, the type species of the genus Saccharomyces, is closely related to species of the genera Kluyveromyces, Torulaspora, and Zygosaccharomyces. The genus Kluyveromyces has been shown to display particularly marked phylogenetic heterogeneity (5), with some of its species phylogenetically intermixed with species belonging to the genera Saccharomyces, Torulaspora, and Zygosaccharomyces. In this study we determined the almost complete 18S rRNA gene sequences of all currently recognized Saccharomyces species, and below we de- 
TABLE 1. Yeast strains compared in this study and their $18 \mathrm{~S}$ rRNA gene sequence accession numbers

\begin{tabular}{|c|c|c|}
\hline Species & Strain $^{a}$ & $\begin{array}{l}\text { EMBL acces- } \\
\text { sion no. }\end{array}$ \\
\hline Candida holmii & NCYC $137^{\mathrm{T}}$ & $\mathrm{X} 97808^{b}$ \\
\hline Kazachstania viticola & CBS $6463^{\mathrm{T}}$ & $\mathrm{X} 99526^{b}$ \\
\hline Kluyveromyces aestuarii & CBS $4438^{\mathrm{T}}$ & $\mathrm{X} 89520$ \\
\hline Kluyveromyces africanus & CBS $2517^{\mathrm{T}}$ & X89519 \\
\hline Kluyveromyces blattae & CBS $6284^{T}$ & X89521 \\
\hline Kluyveromyces delphensis & NCYC $768^{\mathrm{T}}$ & $\mathrm{X} 83823$ \\
\hline Kluyveromyces dobzhanskii & NCYC $538^{\mathrm{T}}$ & $\mathrm{X} 83822$ \\
\hline Kluyveromyces lactis & IFO 1267 & X51830 \\
\hline Kluyveromyces lodderae & NCYC $1417^{\mathrm{T}}$ & X83824 \\
\hline Kluyveromyces marxianus var. bulgaricus & NCYC $970^{\mathrm{T}}$ & X89524 \\
\hline Kluyveromyces marxianus var. marxianus & CBS $712^{\mathrm{T}}$ & $\mathrm{X} 89523$ \\
\hline Kluyveromyces marxianus var. wikenii & CBS $5671^{\mathrm{T}}$ & X89522 \\
\hline Kluyveromyces phaffii & CBS $4417^{T}$ & X89525 \\
\hline Kluyveromyces polysporus & NCYC $523^{\mathrm{T}}$ & $\mathrm{X} 83825$ \\
\hline Kluyveromyces thermotolerans & CBS $6340^{\mathrm{T}}$ & X89526 \\
\hline Kluyveromyces waltii & CBS $6430^{\mathrm{T}}$ & X89527 \\
\hline Kluyveromyces wickerhamii & NCYC $546^{\mathrm{T}}$ & X83826 \\
\hline Kluyveromyces yarrowii & CBS $8242^{\mathrm{T}}$ & X89528 \\
\hline Saccharomyces barnettii & CBS $5648^{\mathrm{T}}$ & $\mathrm{X} 97778^{b}$ \\
\hline Saccharomyces bayanus & CBS $380^{\mathrm{T}}$ & $\mathrm{X} 97777^{b}$ \\
\hline Saccharomyces castellii & CBS $4309^{\mathrm{T}}$ & $\mathrm{Z} 75577^{b}$ \\
\hline Saccharomyces cerevisiae & NCYC $505^{\mathrm{T}}$ & $\mathrm{Z} 75578^{b}$ \\
\hline Saccharomyces dairensis & $\mathrm{NCYC} 777^{\mathrm{T}}$ & $\mathrm{Z} 75579^{b}$ \\
\hline Saccharomyces exiguus & NCYC $814^{\mathrm{T}}$ & $\mathrm{X} 98868^{b}$ \\
\hline Saccharomyces kluyveri & NCYC $543^{\mathrm{T}}$ & $\mathrm{Z} 75580^{b}$ \\
\hline Saccharomyces paradoxus & CBS $432^{\mathrm{T}}$ & $\mathrm{X} 97806^{b}$ \\
\hline Saccharomyces pastorianus & $\mathrm{NCYC} 392^{\mathrm{T}}$ & $\mathrm{X} 97805^{b}$ \\
\hline Saccharomyces rosinii & CBS $7127^{\mathrm{T}}$ & $X 99524^{b}$ \\
\hline Saccharomyces servazzii & CBS $4311^{\mathrm{T}}$ & $\mathrm{Z} 75581^{b}$ \\
\hline Saccharomyces spencerorum & CBS $3019^{\mathrm{T}}$ & $\mathrm{X} 97807^{b}$ \\
\hline Saccharomyces transvaalensis & CBS $2186^{\mathrm{T}}$ & $\mathrm{X} 99522^{b}$ \\
\hline Saccharomyces unisporus & NCYC $971^{T}$ & $\mathrm{Z} 75582^{b}$ \\
\hline Saccharomyces martiniae sp. nov. & CBS 6334 & $\mathrm{X} 99525^{b}$ \\
\hline Saccharomyces sp. & CBS 6904 & $\times 99527^{b}$ \\
\hline Saccharomyces kunashirensis sp. nov. & CBS 7662 & $\mathrm{X} 99523^{b}$ \\
\hline Torulaspora delbrueckii & CBS $1146^{\mathrm{T}}$ & $\mathrm{X} 98120$ \\
\hline Torulaspora globosa & NCYC $820^{\mathrm{T}}$ & X84639 \\
\hline Torulaspora pretoriensis & NCYC $524^{\mathrm{T}}$ & X84638 \\
\hline Zygosaccharomyces bailii & NCYC $1416^{T}$ & X91083 \\
\hline Zygosaccharomyces bisporus & NCYC $1495^{\mathrm{T}}$ & X91084 \\
\hline Zygosaccharomyces cidri & NCYC $1567^{\mathrm{T}}$ & X91085 \\
\hline Zygosaccharomyces fermentati & CBS $707^{\mathrm{T}}$ & $\times 77930$ \\
\hline Zygosaccharomyces florentinus & CBS $746^{\mathrm{T}}$ & X91086 \\
\hline Zygosaccharomyces mellis & NCYC $2403^{T}$ & X90755 \\
\hline Zygosaccharomyces microellipsoides & CBS $427^{\mathrm{T}}$ & X90756 \\
\hline Zygosaccharomyces mrakii & CBS $4218^{\mathrm{T}}$ & $\mathrm{X} 90757$ \\
\hline Zygosaccharomyces rouxii & NCYC $568^{\mathrm{T}}$ & X90758 \\
\hline
\end{tabular}

a NCYC, National Collection of Yeast Cultures, Norwich, United Kingdom CBS, Centraalbureau voor Schimmelcultures, Delft, The Netherlands; IFO, In stitute of Fermentation, Osaka, Japan.

${ }^{b}$ Sequence determined in this study.

scribe the intra- and intergeneric phylogenetic relationships of these organisms. Based on our findings and the results of previous studies, two new Saccharomyces species are described below.

\section{MATERIALS AND METHODS}

Yeast strains and cultivation. The yeast strains examined in this study are listed in Table 1. Strains were obtained from the National Collection of Yeast Cultures, Norwich, United Kingdom, and the Centraalbureau voor Schimmelcultures, Delft, The Netherlands. All strains were grown on YM agar $(0.3 \%$ yeas extract, $0.3 \%$ malt extract, $0.5 \%$ peptone, $1 \%$ glucose, $20 \%$ agar; $\mathrm{pH} 5.5$ ) at $25^{\circ} \mathrm{C}$. PCR amplification and determination of the $18 S$ rRNA gene sequences. The $18 \mathrm{~S}$ rRNA genes were amplified either directly from single yeast colonies, as described by James et al. (11), or from genomic DNA, as described by Cai et al.
(5). The amplified products were purified either by using a Wizard PCR cleaning kit (Promega, Madison, Wis.) or by using a QIAGEN PCR purification kit (QIAGEN, Dorking, United Kingdom) according to the manufacturer's instructions. Direct sequencing of the purified PCR products was performed either manually by using $\alpha-{ }^{35}$ S-dATP and a Sequenase, version 2.0, sequencing kit (United States Biochemical Corp., Cleveland, Ohio), as described by Hutson et al. (10), or by using a Taq DyeDeoxy terminator cycle sequencing kit (Applied Biosystems, Inc., Foster City, Calif.) and an Applied Biosystems model 373A automatic DNA sequencer.

Analysis of sequence data. The $18 \mathrm{~S}$ rRNA gene sequences were aligned by using the multiple-sequence alignment program PILEUP (8) contained in the Genetics Computer Group software package (6), version 7.2. The alignments were adjusted manually. Phylogenetic analyses were performed by using the PHYLIP phylogeny inference package (7), version 3.5. A distance matrix was obtained by using the DNADIST program, and an unrooted phylogenetic tree was constructed by using the neighbor-joining method (21) and the NEIGHBOR program. The stability of the individual branches was assessed by using the bootstrap method with the SEQBOOT, DNADIST, NEIGHBOR, and CONSENSE programs. Species relationships were also investigated by using un weighted pair group with mathematical average (UPGMA) cluster analysis.

Nucleotide sequence accession numbers. The 18S rRNA gene sequences which we determined in this study have been deposited in the EMBL data library under the accession numbers shown in Table 1 .

\section{RESULTS AND DISCUSSION}

The small-subunit rRNA gene sequences of the type strains of all currently recognized Saccharomyces species and three unnamed Saccharomyces strains (CBS $6334^{\mathrm{T}}$ [T $=$ type strain], CBS 6904, and CBS $7662^{\mathrm{T}}$ ) were amplified in vitro by PCR, and their nucleotide sequences were determined directly. These newly determined sequences each consisted of approximately 1,750 nucleotides and represented more than $95 \%$ of the 18S rRNA primary structure. These sequences were aligned with complete or nearly complete $18 \mathrm{~S}$ rRNA gene sequences retrieved from the GenBank and EMBL data libraries for species belonging to the genera Kluyveromyces, Torulaspora, and Zygosaccharomyces and other related taxa. Levels of sequence similarity were calculated (data not shown), and the derived distances were used to infer phylogenetic relationships. Figure 1 shows an unrooted tree constructed by using the neighbor-joining method (21) and depicts the phylogenetic relationships among the 17 Saccharomyces strains examined and other yeast species. The stability of individual branches of the tree was determined by performing a bootstrap analysis (7). A dendrogram was also constructed by using the UPGMA cluster analysis method, and all significant groups $(>90 \%)$ inferred from the neighbor-joining analysis were confirmed (Fig. 2). Some differences in tree topologies were occasionally observed, but these invariably involved branch points supported by low bootstrap values. For example, strain CBS $6334^{\mathrm{T}}$ formed a loose association with Kluyveromyces polysporus and Kluyveromyces yarrowii on the neighbor-joining tree. However, no such relationship was observed on the UPGMA tree, where CBS $6334^{\mathrm{T}}$ exhibited a peripheral association with the Saccharomyces sensu stricto species complex (viz., Saccharomyces bayanus, S. cerevisiae, Saccharomyces paradoxus, and Saccharomyces pastorianus). Little significance can be attached to such movement, as the affinity between CBS $6334^{\mathrm{T}}$ and these other taxa was not supported by high bootstrap resampling values in either analysis. In other cases (e.g., the Zygosaccharomyces bailii group of species), incongruities between the neighbor-joining and UPGMA trees were explicable in terms of marked differences in the branch lengths of some organisms (lack of ultrametricity). As pointed out previously (11), different branch lengths can result in some distortion on a neighborjoining tree, although this effect can be readily identified by referring to UPGMA analysis and sequence relatedness values

It was evident from the results of the phylogenetic analysis that the genus Saccharomyces is not monophyletic and that 


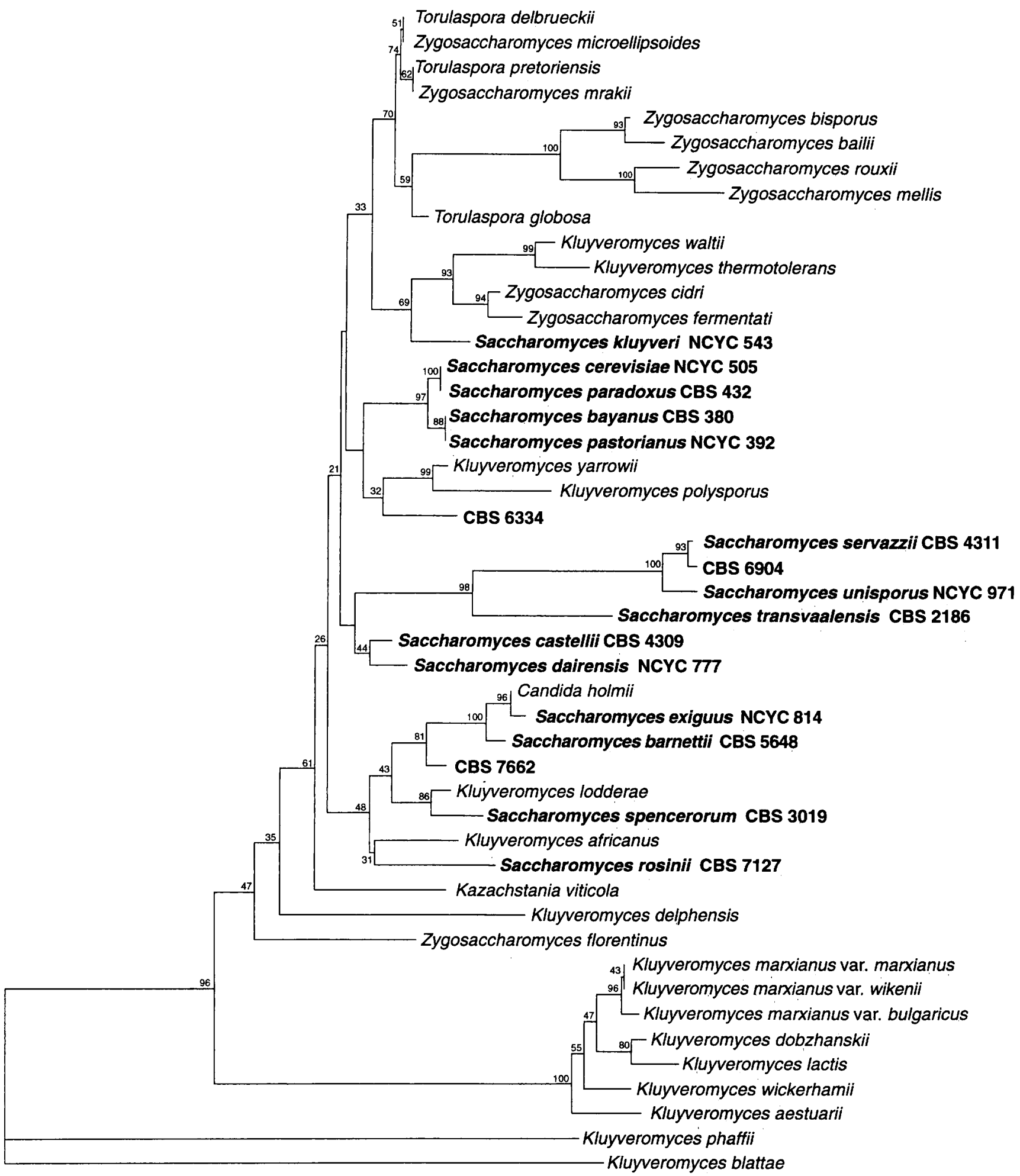

FIG. 1. Dendrogram showing the relationships among species of the genera Kluyveromyces, Saccharomyces, Torulaspora, and Zygosaccharomyces. The tree is based on $18 \mathrm{~S}$ rRNA gene sequence data and was constructed by using the neighbor-joining method. Bootstrap values were calculated from 100 trees. Organisms whose $18 \mathrm{~S}$ rRNA sequences were determined in this study are shown in boldface type.

species of this genus are intermixed with members of other genera, particularly the genera Kluyveromyces and Zygosaccharomyces. Many of the 17 Saccharomyces strains examined exhibited distinct genetic associations with each other and/or with non-Saccharomyces species, while others formed individual sublines that displayed little phylogenetic affinity with other species. The inferred phylogenetic groups and relationships are discussed below. A highly significant group was formed by 


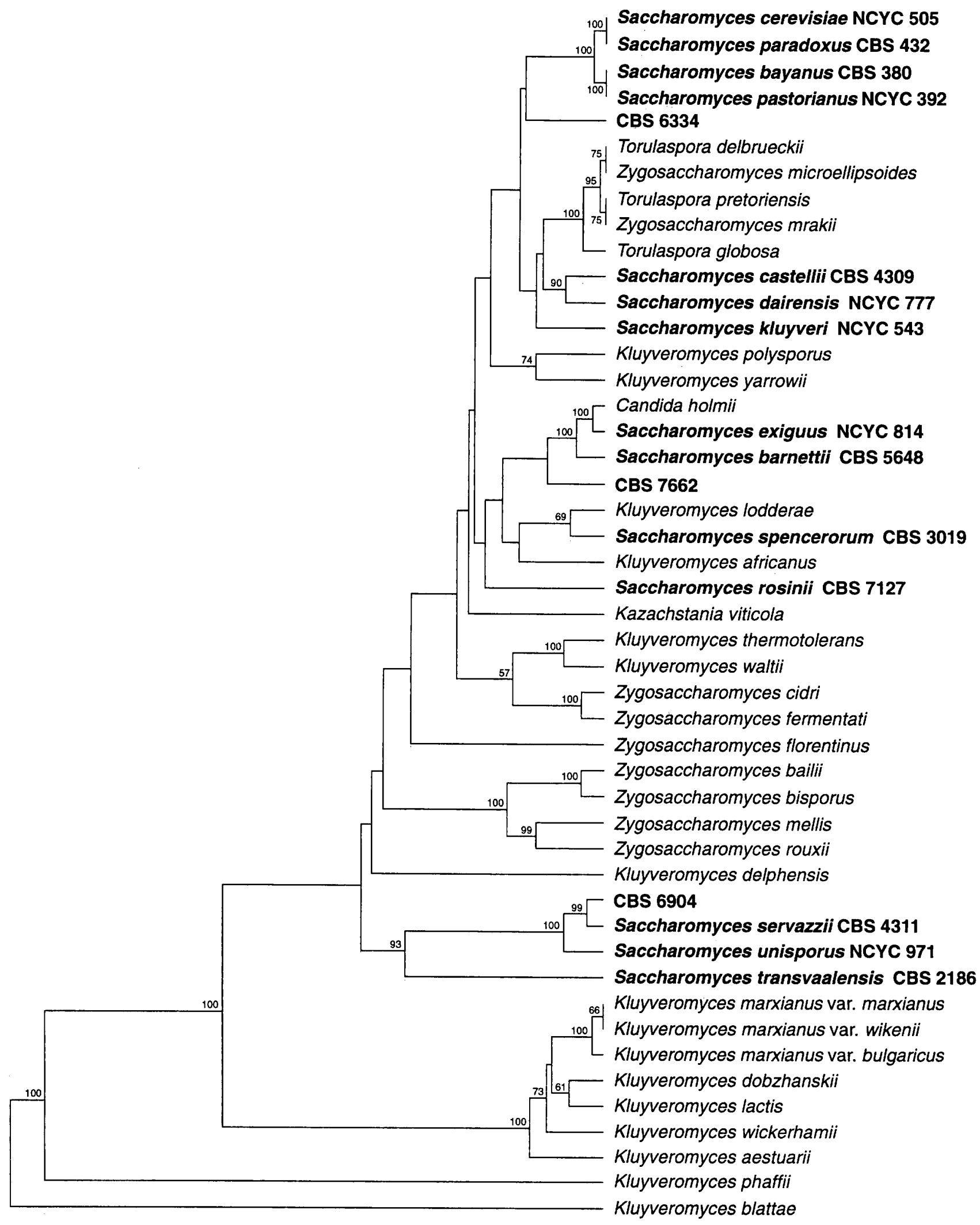

FIG. 2. Dendrogram showing the relationships among species of the genera Kluyveromyces, Saccharomyces, Torulaspora, and Zygosaccharomyces. The tree is based on $18 \mathrm{~S}$ rRNA gene sequence data and was constructed by using the UPGMA method. Bootstrap values were calculated from 100 trees. Only bootstrap values of $\geq 50 \%$ are shown. Organisms whose $18 \mathrm{~S}$ rRNA sequences were determined in this study are shown in boldface type. 
the four species comprising the Saccharomyces sensu stricto species complex (viz., S. bayanus, $S$. cerevisiae, $S$. paradoxus, and $S$. pastorianus). These species were found to be highly related to one another, displaying levels of $18 \mathrm{~S}$ rRNA sequence similarity of $\geq 99.9 \%$, and were phylogenetically separate from members of the Saccharomyces sensu lato complex and non-Saccharomyces species. S. cerevisiae and S. paradoxus were found to be phylogenetically inseparable on the basis of $18 \mathrm{~S}$ rRNA gene sequences, as were $S$. bayanus and $S$. pastorianus. Peterson and Kurtzman (18) previously reported that the latter two species have identical sequences in six regions of their large- and small-subunit rRNAs. The exceptionally close genealogical affinities of the four species of the Saccharomyces sensu stricto complex are consistent with the high overall phenotypic resemblance exhibited by these organisms (2). Recent studies have shown, however, that it is possible to distinguish among the four species of the Saccharomyces sensu stricto complex by using a combination of phenotypic traits (e.g., growth temperature [28], fructose transport activity [20], growth in vitamin-free media [28], and assimilation of D-mannitol [28]). Similarly, despite their close phylogenetic relatedness, nDNA-nDNA reassociation studies $(25,27)$, genetic analyses (1), and ribosomal DNA restriction analysis (16) have shown that $S$. bayanus, $S$. cerevisiae, and $S$. pastorianus represent distinct species. $S$. pastorianus exhibits intermediate nDNA homology values with $S$. bayanus and $S$. cerevisiae, and it has been suggested that this species could represent a partial amphidiploid which may have arisen from a natural hybridization between $S$. bayanus and $S$. cerevisiae (25).

Saccharomyces sensu lato species were found to be phylogenetically heterogeneous, with some species intermixed with non-Saccharomyces species. Saccharomyces exiguus, its anamorph (Candida holmii), and Saccharomyces barnettii were found to be genealogically highly related (levels of 18S rRNA sequence similarity, 99.8 to $99.9 \%$ ) and formed a stable group (bootstrap value, 100\%). Vaughan-Martini (22) only recently delineated $S$. barnettii as a separate species, distinguishing it from $S$. exiguus on the basis of nDNA-nDNA reassociation values. These species are also phenotypically highly related, although they can be differentiated by growth temperature characteristics (22). Strain CBS $7662^{\mathrm{T}}$, which was received as Saccharomyces transvaalensis, formed a distinct subline closely related (level of $18 \mathrm{~S}$ rRNA sequence similarity, 99.5\%) to the $S$. barnettii-S. exiguus group. An unnamed Saccharomyces strain (strain CBS $7662^{\mathrm{T}}$ ) that was originally isolated from the area around a hot spring on Kunashir Island, Russia, was found to be genealogically far removed (Fig. 1) from the type strain of $S$. transvaalensis, strain CBS 2168 , exhibiting about $2 \% 18 \mathrm{~S}$ rRNA sequence divergence. The phylogenetic separateness of CBS $2168^{\mathrm{T}}$ and CBS $7662^{\mathrm{T}}$ is consistent with recent nDNAnDNA reassociation data (23) which showed that the two strains exhibited less than 50\% nDNA homology. The species Saccharomyces spencerorum and Kluyveromyces lodderae were found to be genealogically highly related to one another (level of $18 \mathrm{~S}$ rRNA sequence divergence, $0.3 \%$ ) and formed a loose phylogenetic association with the $S$. barnettii-S. exiguus group (Fig. 1). Similarly, Kluyveromyces africanus and the recently described organism Saccharomyces rosinii (24) exhibited relatively high levels of $18 \mathrm{~S}$ rRNA relatedness (98.8 to $99.4 \%$ ) with the organisms mentioned above, although bootstrap resampling data indicate that their association with $S$. barnettii (and its relatives), $S$. spencerorum, and $K$. lodderae may not be significant (Fig. 1).

Saccharomyces servazzii and Saccharomyces unisporus were found to be genealogically highly related to each other (level of 18S rRNA sequence similarity, 99.8\%). These species, together with Saccharomyces dairensis CBS 6904, formed a statistically highly significant phylogenetic group distinct from other Saccharomyces and non-Saccharomyces species. The close genotypic affinity among these species and their separateness from other taxa are consistent with previous phylogenetic findings (15) based on partial small- and large-subunit rRNA sequences. It is pertinent to note that on the basis of phenotypic criteria $S$. servazzii and $S$. unisporus are considered outlying members of the genus Saccharomyces. For example, S. servazzil and $S$. unisporus display low fermentative profiles and in addition are capable of growth in the presence of $1,000 \mathrm{ppm}$ of cycloheximide, a property characteristic of these two species. Our findings are consistent with the phenotypic distinctiveness of $S$. servazzii and $S$. unisporus and demonstrate that these organisms are phylogenetically quite separate from other currently described species of the genus Saccharomyces. It is also clear from this study, as well as from a recent nDNA-nDNA reassociation experiment (23), that strain CBS 6904 is not an authentic strain of $S$. dairensis. Strain CBS 6904 is clearly a member of the $S$. servazzii-S. unisporus clade, although additional genotypic investigations (e.g., nDNA-nDNA hybridizations) are necessary to determine whether this organism is a strain of $S$. servazzii or represents a hitherto unknown species.

The type strains of Saccharomyces castellii and $S$. dairensis were found to be phylogenetically very highly related (level of 18S rRNA sequence similarity, $99.8 \%$ ). Interestingly, in the neighbor-joining analysis the cluster formed by these two species was found to have a low level of statistical significance (bootstrap value, $<50 \%$ ) despite the fact that the sequences of the organisms differed by only four nucleotides. However, in a UPGMA analysis $S$, castellii and $S$. dairensis grouped together with a high degree of confidence (bootstrap value, $90 \%$ ). The low bootstrap resampling value obtained in the neighbor-joining analysis almost certainly resulted from the exceptionally short stalks of $S$. castellii and $S$. dairensis (Fig. 1). James et al. (12) recently encountered a similar problem in a neighborjoining analysis of Torulaspora globosa, which failed to cluster with its close relatives (viz., Torulaspora delbrueckii, Torulaspora pretoriensis, Zygosaccharomyces microellipsoides, and $Z y$ gosaccharomyces mrakii) despite exceptionally high levels of sequence relatedness $(>99.7 \%)$. It is important to note that $S$. castellii and $S$. dairensis cannot reliably be distinguished from each other by using conventional physiological criteria (28), and on this basis Yarrow (31) considered $S$. castellii a synonym of $S$. dairensis. However, nDNA-nDNA reassociation studies by Vaughan-Martini and Kurtzman (26) have shown that the two species are genotypically distinct, a finding confirmed in our phylogenetic analysis. Type strain CBS 2168 of the recently reinstated species $S$. transvaalensis (29) was found to form a distinct subline, which exhibited no particularly close affinity with any other yeast species examined. $S$. transvaalensis CBS $2168^{\mathrm{T}}$ formed a statistically significant association (bootstrap value, $98 \%$ ) (Fig. 1) with the S. servazzii-S. unisporus group, although sequence divergence considerations showed that the relationship is quite distant. Despite the fact that $S$. transvaalensis CBS $2168^{\mathrm{T}}$ is phenotypically similar to both $S$. castellii and $S$. dairensis, differing only in ascospore morphology (29), it is clear from our analysis that strain CBS $2168^{\mathrm{T}}$ is only a distant phylogenetic relative of the latter two species.

One of the remaining Saccharomyces spp. examined, Saccharomyces kluyveri, formed a distinct subline. S. kluyveri displayed relatively high levels of $18 \mathrm{~S}$ rRNA sequence relatedness ( 98.7 to $99.4 \%$ ) with a variety of organisms (e.g., the genus Saccharomyces sensu stricto, Torulaspora spp., Zygosaccharomyces cidri, Zygosaccharomyces fermentati, Kluyveromyces waltii, and Kluyveromyces thermotolerans), but a treeing analysis 
revealed no particularly significant phylogenetic association with any of these taxa. Similarly, Saccharomyces sp. strain CBS $6334^{\mathrm{T}}$ formed a distinct phylogenetic entity (Fig. 1). Until recently, Saccharomyces sp. strain CBS $6334^{\mathrm{T}}$ was classified on the basis of conventional physiological criteria as a strain of $S$. dairensis. However, both nDNA-nDNA reassociation results (23) and electrophoretic karyotyping (17) have clearly shown that this strain is distinct from $S$. dairensis. The results of our study confirm that strain CBS $6334^{\mathrm{T}}$ is only remotely related to $S$. dairensis and indicate that this organism exhibits a closer phylogenetic affinity with other members of the genus Saccharomyces (e.g., Saccharomyces sensu stricto) and some Kluyveromyces species ( $K$. polysporus and $K$. yarrowii). A treeing analysis, however, revealed no statistically significant phylogenetic associations between strain CBS $6334^{\mathrm{T}}$ and these other organisms.

Recently, great progress has been made in clarifying the genotypic relationships of members of the genus Saccharomyces. In particular, nDNA-nDNA reassociation studies $(23,25$ 27) have provided valuable taxonomic insights at the species level. Analyses of short sequences derived from small- and large-subunit rRNAs have also revealed considerable genealogical diversity within the genus Saccharomyces (15). However, the investigation of Kurtzman and Robnett (15) did not include closely related ascomycetous taxa. In a previous study we demonstrated considerable phylogenetic heterogeneity and intermixing of species in the genera Kluyveromyces, Torulaspora, and Zygosaccharomyces by analyzing almost complete 18S rRNA sequences (5). In this study we extended the analysis mentioned above and included all currently recognized species of the genus Saccharomyces in order to investigate the intra- and intergeneric relationships of these organisms. It is evident from the results of the sequence analysis that the genus Saccharomyces is not monophyletic. Although members of the Saccharomyces sensu stricto complex formed a tight and welldefined phylogenetic group, Saccharomyces sensu lato species were phylogenetically very diverse, with some species interspersed with non-Saccharomyces species and other species forming individual sublines or groups (Fig. 1). It is clear that the phylogenetic structures revealed in this study and a previous study (5) differ markedly from the current phenotypic classification of the genus Saccharomyces and related genera. Although it was not the objective of this study to formally propose a new taxonomic framework for the genus Saccharomyces and its close relatives (e.g., the genera Kluyveromyces and Zygosaccharomyces) along phylogenetic lines, it seems clear that any restructuring will result in a proliferation of new genera. Some yeast species (e.g., Torulaspora species, Z. microellipsoides, and Z. mrakii; species of the Saccharomyces sensu stricto complex) form phylogenetically distinct groups with sufficient phenotypic coherence that they can readily be equated with genera. However, some other species form individual lines or sublines and exhibit only loose associations with other organisms. The taxonomic rank of many of these organisms may prove to be far more problematic. It is important to point out that subdivision into more manageable phylogenetic units may simplify the search for suitable characteristics which allow phenotypic circumscription and differentiation of new genera, which is a major obstacle in constructing a naturally based classification for the ascomycetous yeasts. It is evident from this study that the phylogenetic coherence of the genus Saccharomyces sensu stricto is such that this taxon should form the nucleus of any redefined genus Saccharomyces.

Based on the phylogenetic distinctiveness of Saccharomyces spp. strains CBS $6334^{\mathrm{T}}$ and CBS $7662^{\mathrm{T}}$ and the results of previous studies $(17,23)$, we formally propose that these or- ganisms should be elevated to the rank of new species. We recognize, however, that this is a phenotypic placement of convenience which may require revision when a taxonomic revision of the genus Saccharomyces and its close relatives is made in the future. For strain CBS $7662^{\mathrm{T}}$ we propose the name Saccharomyces kunashirensis, which refers to the locality where the organism was isolated. The name Saccharomyces martiniae is proposed for strain CBS $6334^{\mathrm{T}}$, in honor of Anne VaughanMartini for her many contributions to the taxonomy of the genus Saccharomyces.

Description of Saccharomyces kunashirensis sp. nov. Saccharomyces kunashirensis (ku.na.shi.ren'sis. L. adj. kunashirensis, pertaining to Kunashir Island, where the yeast was originally isolated).

In medio liquido cum glucoso et peptono et extracto levidinis (post dies $3,24^{\circ} \mathrm{C}$ ) cellulae rotundae vel ovoideae, 3.0 $5.0 \times 3.0-5.0 \mu \mathrm{m}$, singulae aut binae. Pseudohyphae nullae. Ascosporae rotundae aut ovoidae, 1-2 in asco.

Glucosum, sucrosum, et galactosum fermentantur at non maltosum, lactosum, cellobiosum, trehalosum, melibiosum, melezitosum, raffinosum, $\alpha$-methylum-D-glucosidum, inulinum, nec amylum.

Glucosum, galactosum, trehalosum, glycerinum, et glucono$\delta$-lactonum assimilantur at non L-sorbosum, sucrosum, maltosum, cellobiosum, lactosum, melibiosum, raffinosum, melezitosum, inulinum, amidum, D-xylosum, L-arabinosum, D-arabinosum, D-ribosum, L-rhamnosum, alcohol aethylicum, erythritolum, ribitolum, galactitolum, D-mannitolum, D-glucitolum, $\alpha$-methylum-D-glucosidum, salicinum, acidum lacticum, acidum succinicum, acidum citricum, inositolum, D-glucosaminum, metanolum, nec xylitolum.

Nitras kalicus, lysinum, cadaverinum, nec ethylaminum non assimilantur.

Non crescere potest in $10 \% \mathrm{NaCl}-5 \%$ glucoso nec cycloheximido $(0.1 \mathrm{~g} /$ litrum).

Typus depositus in collectione Centraalbureau voor Schimmelcultures, Delphi, Nederlandia (CBS 7662), et Collezione dei Lieviti Industriali, Perusia, Italia (DBVPG 6756).

On morphology agar, after $48 \mathrm{~h}$ of growth at $24^{\circ} \mathrm{C}$, the cells are spherical to ovoid and 3.0 to 5.0 by 3.0 to $5.0 \mu \mathrm{m}$ and occur singly or in pairs (Fig. 3). Budding is multipolar. No pseudohyphae are observed in cultures grown on corn meal agar, potato agar, and morphology agar. Oval asci containing two round to oval ascospores are formed after incubation for 3 weeks at $24^{\circ} \mathrm{C}$ on corn meal agar. Ferments glucose, sucrose, and galactose. Does not ferment maltose, lactose, cellobiose, trehalose, melibiose, melezitose, raffinose, $\alpha$-D-glucoside, inulin, or starch. Assimilates glucose, galactose, trehalose, glycerol, and D-glucono-1,5-lactone. Does not assimilate L-sorbose, sucrose, maltose, cellobiose, lactose, melibiose, raffinose, melezitose, inulin, starch, D-xylose, L-arabinose, D-arabinose, D-ribose, L-rhamnose, ethanol, erythritol, ribitol, galactitol, D-mannitol, D-glucitol, $\alpha$-methyl-D-glucoside, salicin, DL-lactate, succinate, citrate, inositol, D-glucosamine, methanol, or xylitol. Does not assimilate cadaverine, lysine, ethylamine hydrogen chloride, or potassium nitrate. No growth occurs in the presence of $0.01 \%$ cycloheximide or on $10 \%(\mathrm{wt} / \mathrm{wt}) \mathrm{NaCl}-5 \%$ glucose agar.

Cultures of the type strain have been deposited in the Centraalbureau voor Schimmelcultures, Delft, The Netherlands (CBS 7662), and the Collezione dei Lieviti Industriali, Perugia, Italy (DBVPG 6756).

Description of Saccharomyces martiniae sp. nov. Saccharomyces martiniae (mar.ti'ni.ae. L. gen. fem. n. martiniae, of Martini, in honor of Ann Vaughan-Martini).

In medio liquido cum glucoso et peptono et extracto levidi- 

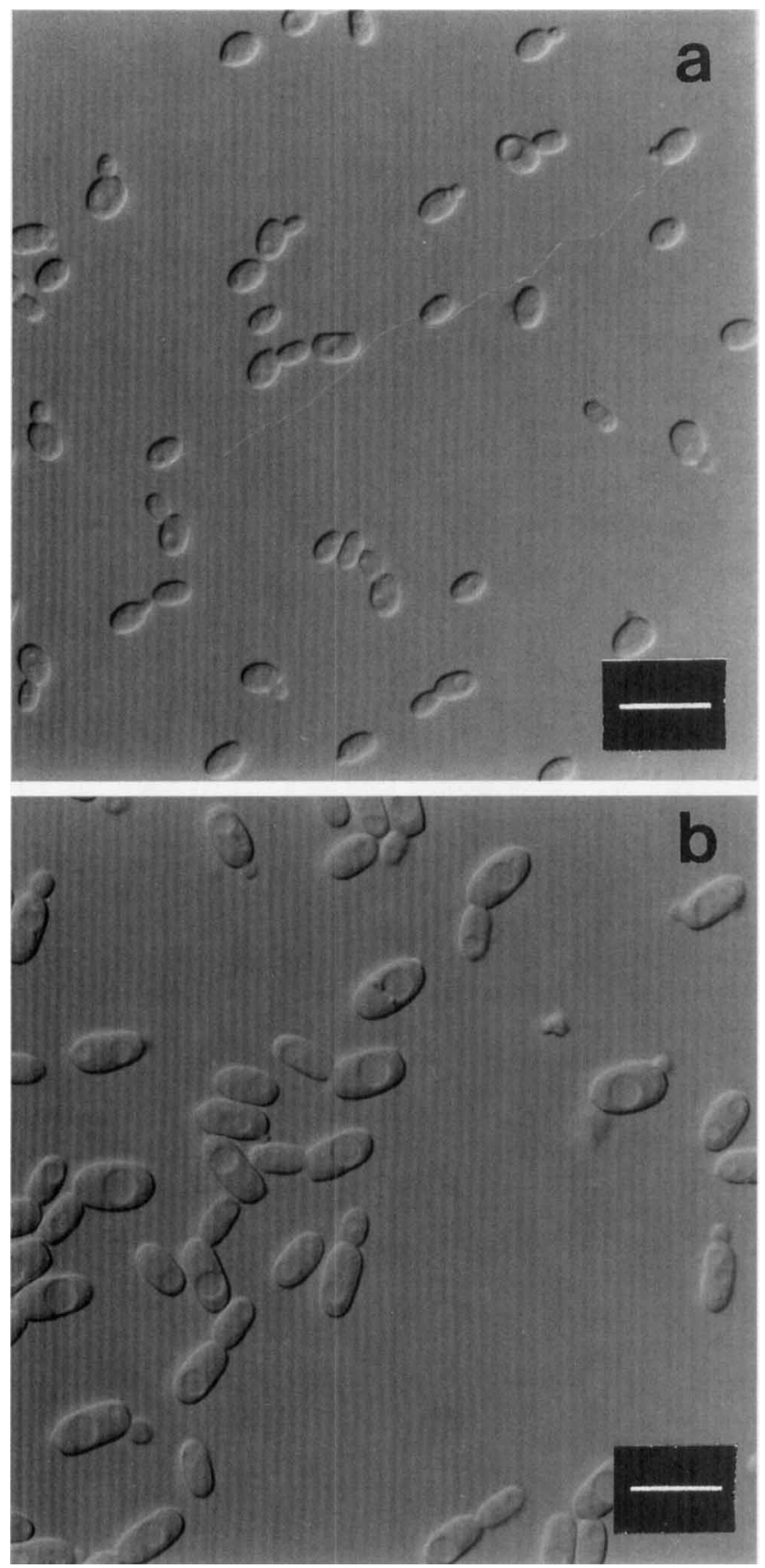

FIG. 3. Vegetative cells of $S$. kunashirensis CBS $7662^{\mathrm{T}}$ (a) and $S$. martiniae CBS $6334^{\mathrm{T}}(\mathrm{b})$. Cells were grown overnight in YNBG medium at $24^{\circ} \mathrm{C}$. Bars $=$ $10 \mu \mathrm{m}$.

nis (post dies $3,24^{\circ} \mathrm{C}$ ) cellulae ovoideae, $2.0-3.0 \times 6.0-9.0$ $\mu \mathrm{m}$, singulae aut binae. Pseudohyphae nullae.

Glucosum, sucrosum, galactosum, et trehalosum fermentantur at non maltosum, lactosum, cellobiosum, melibiosum, melezitosum, raffinosum, $\alpha$-methylum-D-glucosidum, inulinum, nec amylum.

Glucosum, galactosum, trehalosum, et glucono- $\delta$-lactonum assimilantur at non L-sorbosum, sucrosum, maltosum, cellobiosum, lactosum, melibiosum, raffinosum, melezitosum, inulinum, amidum, D-xylosum, L-arabinosum, D-arabinosum, D-ribosum, L-rhamnosum, alcohol aethylicum, glycerinum, erythritolum, ribitolum, galactitolum, D-mannitolum, D-glucitolum, $\alpha$-methylum-D-glucosidum, salicinum, acidum lacticum, acidum succinicum, acidum citricum, inositolum, D-glucosaminum, metanolum, nec xylitolum.

Nitras kalicus, lysinum, cadaverinum, nec ethylaminum non assimilantur.

Non crescere potest in $10 \% \mathrm{NaCl}-5 \%$ glucoso nec cycloheximido $(0.1 \mathrm{~g} / \mathrm{litrum})$.

Typus depositus in collectione Centraalbureau voor Schimmelcultures, Delphi, Nederlandia (CBS 6334), et Collezione dei Lieviti Industriali, Perusia, Italia (DBVPG 6752).

On morphology agar, after $48 \mathrm{~h}$ of growth at $24^{\circ} \mathrm{C}$, the cells are ovoid and 2.0 to 3.0 by 6.0 to $9.0 \mu \mathrm{m}$ and occur singly or in pairs (Fig. 3). Budding is multipolar. No pseudohyphae are observed in cultures grown on corn meal agar, potato agar, and morphology agar. Ferments glucose, sucrose, galactose, and trehalose. Does not ferment maltose, lactose, cellobiose, melibiose, melezitose, raffinose, $\alpha$-D-glucoside, inulin, or starch. Assimilates glucose, galactose, trehalose, and D-glucono-1,5lactone. Does not assimilate L-sorbose, sucrose, maltose, cellobiose, lactose, melibiose, raffinose, melezitose, inulin, starch, D-xylose, L-arabinose, D-arabinose, D-ribose, L-rhamnose, ethanol, glycerol, erythritol, ribitol, galactitol, D-mannitol, D-glucitol, $\alpha$-methyl-D-glucoside, salicin, DL-lactate, succinate, citrate, inositol, D-glucosamine, methanol, or xylitol. Does not assimilate cadaverine, lysine, ethylamine hydrogen chloride, or potassium nitrate. No growth occurs in the presence of $0.01 \%$ cycloheximide or on $10 \%$ (wt/wt) $\mathrm{NaCl}-5 \%$ glucose agar.

Cultures of the type strain have been deposited in the Centraalbureau voor Schimmelcultures, Delft, The Netherlands (CBS 6334), the Institute of Fermentation, Osaka, Japan (IFO 0752), and the Collezione dei Lieviti Industriali, Perugia, Italy (DBVPG 6752)

\section{ACKNOWLEDGMENTS}

We are indebted to the European Community (Agricultural Industrial Research Programme contract CT93-0830) for support.

We thank Chris Bond and Laura Weldon at the National Collection of Yeast Cultures for technical assistance and James and Linda Barnett for kindly providing the photomicrographs.

\section{REFERENCES}

1. Banno, I., and Y. Kaneko. 1989. A genetic analysis of taxonomic relation between Saccharomyces cerevisiae and Saccharomyces bayanus. Yeast 5(Special Issue):S373-S377.

2. Barnett, J. A., R. W. Payne, and D. Yarrow. 1990. Yeasts: characteristics and identification, 2nd ed. Cambridge University Press, Cambridge, United Kingdom.

3. Barnett, J. A. 1992. The taxonomy of the genus Saccharomyces Meyen ex Reess: a short review for non-taxonomists. Yeast 8:1-23.

4. Barns, S. M., D. J. Lane, M. L. Sogin, C. Bibeau, and W. G. Weisburg. 1991 Evolutionary relationships among pathogenic Candida species and relatives. J. Bacteriol. 173:2250-2255.

5. Cai, J., I. N. Roberts, and M. D. Collins. 1996. Phylogenetic relationships among members of the ascomycetous yeast genera Brettanomyces, Debaryo myces, Dekkera, and Kluyveromyces deduced by small-subunit rRNA gene sequences. Int. J. Syst. Bacteriol. 46:542-549.

6. Devereux, J., P. Haeberli, and D. Smithies. 1984. A comprehensive set of sequence analysis programs for the VAX. Nucleic Acids Res. 12:387-395.

7. Felsenstein, J. 1993. PHYLIP: phylogenetic inference package, version 3.5 University of Washington, Seattle.

8. Feng, D. F., and R. F. Doolittle. 1987. Progressive sequence alignment as a prerequisite to correct phylogenetic trees. J. Mol. Evol. 35:351-360.

9. Hendriks, L., A. Goris, Y. Van de Peer, J.-M. Neefs, M. Vancanneyt, K. Kersters, J.-F. Berny, G. L. Hennebert, and R. De Wachter. 1992. Phylogenetic relationships among ascomycete and ascomycete-like yeasts as deduced from ribosomal small-subunit RNA sequences. Syst. Appl. Microbiol. 15:98104.

10. Hutson, R. A., D. E. Thompson, and M. D. Collins. 1993. Genetic interrelationships of saccharolytic Clostridium botulinum types B, E and F and related clostridia as revealed by small-subunit rRNA gene sequences. FEMS Microbiol. Lett. 108:103-110. 
11. James, S. A., M. D. Collins, and I. N. Roberts. 1994. Genetic interrelationship among species of the genus Zygosaccharomyces as revealed by smallsubunit rRNA gene sequences. Yeast 10:871-881.

12. James, S. A., M. D. Collins, and I. N. Roberts. 1996. Use of an rRNA internal transcribed spacer region to distinguish phylogenetically closely related species of the genera Zygosaccharomyces and Torulaspora. Int. J. Syst. Bacteriol. 46:189-194.

13. Kurtzman, C. P. 1992. rRNA sequence comparisons for assessing phylogenetic relationships among yeasts (minireview). Int. J. Syst. Bacteriol. 42:1-6.

14. Kurtzman, C. P. 1994. Molecular taxonomy of the yeasts. Yeast 10:17271740 .

15. Kurtzman, C. P., and C. J. Robnett. 1991. Phylogenetic relationships among species of Saccharomyces, Schizosaccharomyces, Debaryomyces and Schwanniomyces determined from partial ribosomal RNA sequences. Yeast 7:61-72.

16. Molina, F. I., T. Inoue, and S.-C. Jong. 1992. Ribosomal DNA restriction analysis reveals genetic heterogeneity in Saccharomyces cerevisiae Meyen ex Hansen. Int. J. Syst. Bacteriol. 42:499-502.

17. Naumov, G. I., E. S. Naumova, and M. Korhola. 1995. Karyotypic relationships among species of Saccharomyces sensu lato: $S$. castellii, $S$. dairensis, $S$. unisporus and S. servazzii. Syst. Appl. Microbiol. 18:103-108.

18. Peterson, S. W., and C. P. Kurtaman. 1991. rRNA sequence divergence among sibling species of yeasts. Syst. Appl. Microbiol. 14:124-129.

19. Price, C. W., G. B. Fuson, and H. J. Phaff. 1978. Genome comparison in yeast systematics: delimitation within the genera Schwanniomyces, Saccharomyces, Debaryomyces, and Pichia. Microbiol. Rev. 42:161-193.

20. Rodrigues de Sousa, H., A. Madeira-Lopes, and I. Spencer-Martins. 1995 The significance of active fructose transport and maximum temperature for growth in the taxonomy of Saccharomyces sensu stricto. Syst. Appl. Microbiol. 18:44-51.
21. Saitou, N., and M. Nei. 1987. The neighbor-joining method: a new method for reconstructing phylogenetic trees. Mol. Biol. Evol. 4:406-425.

22. Vaughan-Martini, A. 1995. Saccharomyces barmettii and Saccharomyces spen cerorum: two new species of Saccharomyces sensu lato (van der Walt). Antonie van Leeuwenhoek J. Microbiol. 68:111-118.

23. Vaughan-Martini, A., and S. Barcaccia. 1996. A reconsideration of specie related to Saccharomyces dairensis (Naganishi). Int. J. Syst. Bacteriol. 46: 313-317.

24. Vaughan-Martini, A., S. Barcaccia, and P. Pollacci. 1996. Saccharomyces rosinii sp. nov., a new species of Saccharomyces sensu lato (van der Walt) Int. J. Syst. Bacteriol. 46:615-618.

25. Vaughan-Martini, A., and C. P. Kurtzman. 1985. Deoxyribonucleic acid relatedness among species of the genus Saccharomyces sensu stricto. Int. J. Syst. Bacteriol. 35:508-511.

26. Vaughan-Martini, A., and C. P. Kurtzman. 1988. Deoxyribonucleic acid relatedness among species of Saccharomyces sensu lato. Mycologia 80:241243.

27. Vaughan-Martini, A., and A. Martini. 1987. Three newly delimited species of Saccharomyces sensu stricto. Antonie van Leeuwenhoek J. Microbiol. 53:7784.

28. Vaughan-Martini, A., and A. Martini. 1993. A taxonomic key for the genus Saccharomyces. Syst. Appl. Microbiol. 16:113-119.

29. Vaughan-Martini, A., and P. Pollacci. 1996. Synonomy of the yeast genera Saccharomyces Meyen ex Hansen and Pachytichospora van der Walt. Int. J. Syst. Bacteriol. 46:318-320.

30. Woese, C. R. 1987. Bacterial evolution. Microbiol. Rev. 51:221-271.

31. Yarrow, D. 1984. Saccharomyces Meyen ex Reess, p. 379-395. In N. J. W. Kreger-van Rij (ed.), The yeasts: a taxonomic study, 3rd ed. Elsevier Science Publishers, Amsterdam, The Netherlands. 